\title{
Kenneth Burke's Dramatist Pentad as an Alternative Approach to Art Criticism in the Classroom
}

\author{
Gayle Weitz
}

Since the advent of discipline-based art education (DBAE), the content of art education has sought to encompass more than the production of studio projects by including aesthetics, art history, and art criticism in the curriculum. Immanuel Barkan is cited as the first to both question the prevailing studio emphasis and propose broadening the content of art to include aesthetics, art history, and criticism (Lanier, 1983). He strongly suggested more talk about art and less production of it in his influential paper presented at The Pennsylvania State University Seminar in 1965 (Barkan, 1966). Many art educators echoed the sentimient to expand the content of art to include discourse on art (Broudy 1972; Efland 1967; Eisner 1966; Goodland 1979; Lanier 1962, 1963; Marantz, 1964, 1967, 1971; McFee, 1961). Now more than twenty years later, studio activity still dominates art education, but talk about art or art criticism has been incorporated, to some degree, into nearly every contemporary art curriculum and instructional text (Duvall, 1986; Johansen, 1982; Clark, 1973; Carpentier, 1987).

So what is art criticism, who partakes in it, and what benefits are derived from the experience? Generally speaking, art criticism entails verbal commentary (criticism) about visual objects (art). This commentary could be as simple as one child saying to another, "...cool shirt you're wearing today, Chris;" to something as complex as one art history professor remarking to another, ". . . the transformation of the political symbolism of the Pallazzo Vecchio embodied in Michelozzo's new cortile may have involved yet another dimension, at the level of conscious intent rather than mere historical drift" (Trachtenberg, 1989, p. 606). The difference between these comments reveals some of the issues associated with art criticism: What constitutes legitimate art criticism? Who is capable of delivering such commentary? What objects are designated art, the subject of criticism? And by whose standards will these objects be judged? These issues point to fundamental components of art criticism -- the relationships among viewer, art form, artist, and culture, at specific points in time.

What is the relationship between art and society? What is art and who determines this: the artist, the viewer, and/or society? How does commentary on art differ from commentary on non-art? What is an aestheiic experience, and is this a necessary ingredient of art criticism? What part does the viewer, artist, and culture play in the interpretation of art? What is the role of art criticism in society? Does criticism vary between cultures and/or over time? Various answers to these questions result from different orientations to 
the relationships between the components -- artist, viewer, art form, and culture -- and yield numerous theories of art criticism.

My personal orientation to art criticism centers on the cultural component. Many art theorists take this contextual position (Beyer, 1981; Burke, 1968; Christian-Smith, 1987; Clark, 1973; Donahue, 1985; Duncum, 1987; Geertz, 1976; Goronov, 1981; Lanier, 1963; Petkus, 1985; and Wolff, 1975). Janet Wolff (1986) claims that works of art are not self-contained entities, but are the products of specific historical practices, by identifiable groups, in specific conditions. She provides a sociological approach to the study, interpretation, and criticism of art. A sociological approach places the components of artist, viewer, and art object all within the context of culture. I believe that only through the lens of culture do the concepts art form, artist, and viewer, possess meaning. Art is intricately tied to life; its understanding is always in reference to experience (Dewey, 1934).

Within this setting and in its most general sense, art can be defined as anything special -- any thing that is significant beyond the ordinary. These specialized objects (art) are defined on numerous levels: personally, familially, geographically, ethnically, nationally, etc. These various categories of art change and evolve at various rates with time. Everyone with sensory perception differentiates between art and non-art, good and bad art, art they like and art they don't; some more consciously, more often, and more dogmatically than others. So whose judgment is correct? Do some people know more about art than others? Are some objects better art forms than others? It seems to me that convictions of correct, more, or better are all relative terms; terms dependent upon a judgment base. Unless this base is known, one cannot determine correct, more, or better. This is why a contextual view of art criticism is necessary.

The base from which artistic judgments are rendered is not the same for all people. Inherent physiological and mental differences between individuals compounded with various social constructions of reality yield numerous standards of aesthetic judgment. Unless these social constructions are known and shared, with individual differences accounted for, consensus in art is mere chance or totalitarian imposition. What the viewer brings to the art form -- the individual physiological perceptual apparatus plus their cultural of reality plus the timing of the encounter -- all influence how the form is interpreted and valued. Thus art criticism, to be truly understood, must be viewed from a contextual perspective.

Does this mean all criticism and art forms are equal? Only if reality could be stretched to its illogical and unrealistic extreme -- a noncontextual vacuum -- would all objects and critiques be equal. But for humankind, a vacuous world will never exist, therefore all criticism and art forms will never be equal. All critiques in real life are bound to a judgment base which is dependent upon a cultural orientation. One's cultural orientation renders some judgment bases better than others. The same is true for art forms; 
some will be better or worse according to the standards by which they are judged. To seek an almighty Art, or Criticism is as futile as looking for Truth; our avenues of knowing can only reveal truth as our biased perceptions construe it.

The more important aspect of art criticism is not evaluating good art, but rather examining why, how, and in reference to what, judgments are being made. It seems to me that art criticism in its broadest sense is concerned with fostering a vital understanding of the physical manifestations of a culture -perceiving and comprehending the visual products of civilization. Which understanding of which visual products from which context are the major questions art criticism must initially answer. How we answer these questions reveals who we are, where we have been, and how we can affect the future.

Incorporating art criticism into the curriculum is a worthwhile and necessary component of art education. Criticism is considered essential to the acquisition of skills and abilities, to the development of taste, and to enlightened participation in one's culture (Kauffeld, 1989). It is thought to positively strengthen existing art programs by integrating visual and verbal skills into productive interaction involving complex cognitive thinking (Atkins, 1989; Smith, 1983). Teaching criticism is believed to increase perceptual skills, facilitate cognitive development, and even enhance the reading ability in young children (Janov, 1986; Smith, 1983). The National Endowment for the Arts (1988) claims that art education should provide all students with the critical skills necessary to make informed choices about the arts. Art criticism is now commonly practised, to some degree, at all levels in most schools.

Presently, typical classroom art criticism is done in reference to a set of fine arts reproductions -- copies of famous works primarily found in museums and galleries around the Western world (Gordon, 1988). Some art criticism programs are sponsored and/or executed by members of the community and are done in addition to the designated "art time." These include picture study programs, great artists series, mini-museums, etc. More often art criticism is conducted by the art teacher in the classroom as an adjunct to studio production (Landis, 1987). Typical art talk consists of formal comments made in reference to a famous work of art such as The Mona Lisa. The talk generally begins with statements of description, followed by statements of analysis, interpretation, and finally, some sort of judgment or evaluation.

This four-stage process of criticism -- description, analysis, interpretation, evaluation -- is also utilized by most professional art critics (Kostelanetz, 1976; Titchener, 1987; Pepper, 1949). The classroom version is usually attributed to Edmund Feldman (1981), but has its roots in Monroe Beardsley and others (Geahigan, 1979; Feinstein, 1989). According to Feldman the goal of this approach is to slow-down the process of judgment, while enlarging understanding, increasing satisfaction or enjoyment, and developing a set of standards by which to judge art (Feldman, 1981).

Working Papers in Art Education 1989 - 1990 
Feldman describes the four stages as follows: Description consists of taking an inventory -- listing compositional "facts" about the art work while avoiding the drawing of inferences. Analysis consists of describing how the "compositional facts" relate to one another to form a composition, making assertions that would not be subject to disagreement. Interpretation consists of expressing the meaning of the art form, based upon evidence in the work. And evaluation consists of ranking the art form in relation to other works in its class.

This four-stage formalist process remains the approach to art criticism in the schools. It is found in nearly all classroom applications of art criticism and is deemed the "traditional approach" to art criticism in education (Kordich, 1982; Hollingsworth, 1982; Feldman, 1981; Gaitskell et al., 1982; Chapman, 1978; Eisner, 1972; Hurwitz \& Madeja, 1977; Smith, 1967; Barkan and Chapman, 1967; Geahigan, 1979; Clark, 1973).

An influential proponent of this method is The Getty, the multi-milliondollar foundation developing and promoting a discipline-based art education. Members of The Getty describe art criticism as "the skills required to experience, analyze, interpret, and describe the expressive qualities of visual form," firmly echoing the traditional approach (Getty, 1985, p. 17). Here the professional art critic is specifically cited as the role model for students of criticism, while the objects presented for critique are selected from famous works found in various museums (Getty, 1985). Examples of art criticism such as this, emphasizing the four-stage approach, the formalist tradition, the fine arts, and the professional art critic are found in numerous texts and articles in art education (Clark and Zimmerman, 1978; Feinstein, 1989, Borgmann, 1981; Carpentier, 1987; Lankford, 1980; Donahue, 1985; Clark, 1973). It is the dominant method for art talk in a classroom.

Since art talk has now become part of most art curricula, the concern of art educators has shifted from broadening the content of art, to questioning what constitutes worthwhile and legitimate art talk. Incorporating art criticism into the curricula in the traditional manner just described has had little effect on art education (Lanier, 1976). Many claim there is scant evidence of success in students of the development of critical skills and aesthetic sensitivity to perceive visual properties (Arnheim, 1974; Clark, 1973; Lanier, 1976; and Borgmann, 1981). This lack of critical skill is evidenced in the number of Americans naive in the ability to perceive, evaluate, and understand the visual imagery of their culture (Gardner, 1974; Mittler, 1973; Wilson, 1988; Borgmann, 1981). The National Endowment for the Arts (1988) claims that most students have no tools to develop the critical attitudes that would enable them to become discriminating viewers and listeners.

These remarks result in part from the small amount of time allocated to art criticism within the curricula and texts, but largely result from the traditional approach of art criticism used (Early, 1985; Clark, 1973). Art criticism in general needs to be considered more seriously as an important

Working Papers in Art Education 1989 - 1990 
aspect of art education (Lankford, 1980). Traditional classroom art criticism in particular needs to be examined more carefully and perhaps restructured or abandoned (Borgmann, 1981). The traditional four-stage process may not be an adequate approach for public school art criticism.

Most objections to traditional art criticism are aimed at the notions of formalism, the fine arts, and the professional art critic to which the method adheres. Formalism is the general aesthetic orientation behind the four-stage approach. Formalism judges art by the quality of its formal organization -- the elements and principles of design -- inherent in the art object. In its purest sense, formalism does not consider any information that is not inherent in the art object. It ignores all relative information such as cultural contexts and personal circumstances of the viewer (Carpentier, 1987). It examines art as though it exists in a vacuum, providing a method for dealing with all art under the guise of a neutral perspective (Petkus, 1985). However, the price for the apparent neutrality is the exclusion of what constitutes meaningful criticism -the viewer's emotions and the cultural references. "Formalism blinds us to the data upon which comparative understanding can be built" (Geertz, 1979, p. 30). It removes art from the common purview and renders it inaccessible and incapable of being integrated with human activity (Petkus, 1985).

The supposed neutral perspective of formalism obfuscates the reference point from which judgment is made. In formalism, the reference point for judgment comes from the professional art critic, she or he has developed the necessary skills and breadth of knowledge from years of experience and proper education. These experts serve as the high priestess' in art criticism (Clark, 1973). This hierarchical power structure makes the average student feel inadequate in rendering aesthetic judgments, because it locates the standards for judgment outside the individual viewer.

It also puts the critic in the powerful position of defining what constitutes legitimate art. The objects professional critics define as art tend to be the fine arts -- the arts of the rich and powerful -- which comprise but one sector of the totality of visual art forms (Carpentier, 1987). Consequently, traditional art criticism fosters an elitist view of art by disregarding the majority of aesthetic objects which lie outside this domain of the fine arts. "Art" as defined in traditional classroom art criticism is placed beyond the realm of ordinary experience for most people.

This traditional approach to art criticism is being questioned, because of the issues resulting from its connection to formalism, the professional art critic, and the fine arts. Some art educators maintain that art criticism involves more than the perceived attributes of the art object, the artist, the viewer, and the culture(s) in which they exist. All these factors influence the meaning of art and are crucial to defining, understanding, and valuing it. By using formalism as the traditional approach to art criticism, the personal attributes and circumstances of the viewer, as well as the culture(s) in which both art object and viewer exist, have been discounted or ignored. In addition,

Working Papers in Art Education 1989 - 1990 
defining art and the standards by which it is judged has been removed from the individual viewer and relegated to the experts. Isn't there a better approach to art criticism in the public schools?

Is there a model of criticism which allows for a more diverse definition of art, situates the art form and viewer in a cultural context, allows for a panoramic response to art, and still appreciates the inherent visual qualities of the art object? Is there an approach to art criticism that is more democratic and dialectic in nature? To answer these questions, various aesthetic theories and orientations to criticism need to be examined. When judging these domains, many assumptions concerning the role of schools and art come into play. What is the purpose of public education in the United States? What is the function of art education within this institution? How does this relate to the role art serves in our culture and/or in our personal lives? What part should art education play in schools and society? Answers to these questions provide the foundation upon which the need for a new art criticism arises, therefore warrant some brief discussion.

The major purpose of schooling in a democratic society lies somewhere between the divergent goals of perpetuating the status quo (providing continuity and preserving what's good) and fostering social change (allowing for individual differences and improving what's adverse) (Kleibard, 1986). The curriculum pendulum slowly swings between these poles, continually changing the content and approach to education to accommodate the shifts. The whole system is in constant flux with numerous battles being fought on multiple levels at all times. Art criticism is but one area in which some of these battles are played out.

Traditional art criticism employs an approach to curriculum which mainly pursues the goal of status quo. This present dominant methodology is fundamentally a theory of technique, a reconstructed view of the methods employed by the sciences and industry. This borrowed approach, sometimes called the Tyler rationale, social efficiency model, scientific management, or technocratic rationality, is attributed to Ralph W. Tyler (1949). The technocratic rationale is a linear approach that assumes certainty and neutrality. It emphasizes efficiency of means, predictability of outcomes, and manipulation and control of variables. Experts establish policy to ensure control and maintain accountability. Learning is reduced to classroom management, with conflict, variation, and choice avoided (Apple, 1979).

The traditional four-stage approach to criticism exhibits this dominant curriculum methodology in numerous ways. Through formalism, it creates a technical language representing the internal relations of art forms in abstract, transposable terms (Geertz, 1976). This language presents itself as value-free, impartial, and blind to class, race, gender, and time (Rees and Borzello, 1988). Like the technocratic rationale, traditional criticism proceeds in a linear fashion: description, analysis, interpretation, then evaluation. This order is contrary to natural criticism which begins with judgment. Traditional criticism

Working Papers in Art Education 1989 - 1990 
also manipulates and controls the variables of object, viewer, artist, and culture: The art object is controlled through the experts, the professional art critics, who define and select what constitutes "art." The historical and theoretical assumptions operative in this process are suppressed, because the critic speaks as though the criteria applied are self-evident, timeless, laws of nature (Burgin, 1973). The viewer is controlled through formalism's "neutral" analysis of the art object, which originates outside him/her. Through the formalist frame of questioning, the artist and culture are controlled by making then nearly irrelevant. Traditional criticism legitimizes the status quo and provides for continuity through the construction of a national heritage as an ideological site for renewing a selectively conservative vision of the past within the confines of an authoritarian and ritualized present (Rees and Borzello, 1988).

These concerns are now being addressed as the curriculum pendulum swings in the opposite direction toward education for social change and individualism. The methodology used here is referred to as the sociology of curriculum, which places a greater emphasis on the sense of the politics of school knowledge. It challenges the claim that school knowledge is objective, analyzes the role of schools in society, and attempts to understand the relationship between cultural forms and structural limitations (Anyon, 1983; Apple, 1982; MacDonald, 1981; Wexler, 1983). Neo-marxism, the approach commonly employed by the sociology of curriculum theorists, provides a general theory of social organization to which all cultural and social practices can be related. It also provides a procedure to understand the nature of dominant culture and social processes, a range of alternatives, and a fixed point from which to proceed (Duncum, 1987).

From this perspective, art can be viewed as a means of bringing about political, economic, and social change (Crawford, 1987). Control of the arts and the policies and practices associated with them are viewed as culturally and economically biased against those who cannot gain the significance of the dominant aesthetic (Petkus, 1985). The sociology of curriculum provides an educational philosophy upon which objection to the traditional approach to art criticism can be based. It also provides a framework from which to seek an appropriate alternative, one that is contextual and empowers the individual and non-dominant groups. It points to the need for development and refinement of a materialist theory of aesthetics, which re-examines the traditions represented by a concern for disinterestedness, physical distance, presentational features of the object, etc,; and replaces them within a tradition which views aesthetics as important socially, politically, and ethically (Beyer, 1981). It addresses the need to provide aesthetic experiences for students that work toward a more just world (Beyer, 1981).

This philosophical stance in education governs the perspective from which judgments concerning art and art education will be rendered. The focus of this study is to seek a method of art criticism that can be readily used 
in the classroom that coincides with this view of education. An alternative approach to traditional classroom art criticism must address the issues of: defining art, providing a cultural context, allowing a panoramic response, respecting and considering the inherent qualities of the art form, and being democratic and dialectic in nature. This study builds upon present aesthetic theory and approaches to criticism, while working towards a method of criticism that considers: the viewer, art form, artist, within a cultural context.

The limitations of the study are due primarily to its focus. Being pragmatic rather than theoretical, the emphasis will not be to establish a grandiose aesthetic theory and resulting criticism, but rather to seek an existing approach (with possible adaption) that provides a superior alternative from what is presently practised as art criticism in American public schools. The emphasis is on practice, coming up with a model that can be readily used and understood in the $\mathrm{K}-12$ public school setting. The study remains hypothetical in the sense that the new method will not be tested on various populations in specific places. The application of the method will be illustrative of what could be done rather than a test of what is done. (Perhaps future research will result in the actual testing of the method on various populations and situations.)

The method selected as an alternative to the existing views of art criticism is Kenneth Burke's (1968) Dramatist Pentad, a critical method of analysis traditionally applied to literary forms. It is my contention that this critical frame can also be used to examine visual art forms, bringing to art criticism a generative model which enables us to ask a set of relevant questions from a variety of perspectives in reference to any object (Burke, 1945). Dramatism is not being advocated as the methodological end-all/beall, but rather as the most comprehensive alternative to date and a vast improvement over traditional classroom art criticism.

All methods and approaches to art criticism thus far tend to focus on one of the elements -- viewer, art form, artist, culture -- ignoring or minimizing the others. Formalism accentuates the art object, contextualism the culture, psychoanalysis the artist/viewer, etc. Emphasizing one particular element distorts reality and provides a partial view of the entire process. The superiority of Burke's Dramatist Pentad is that it provides a framework which includes all the elements and incorporates other approaches while pointing out their biases.

Burke (1968) defines Dramatism as "a method of analysis and a corresponding critique of terminology designed to show that the most direct route to the study of human relations and human motives is via a methodical inquiry into cycles or clusters of terms and their functions" (p. 9). Through the use of the Pentad, Dramatism considers motives in a perspective that treats language and thought primarily as modes of action. It offers a system of placement which enable various classes of theory to be generated. It reduces the subject synoptically, while still permitting great scope and complexity. It is

Working Papers in Art Education 1989 - 1990 
a marriage of paradox and metaphor that accounts for unity and divisions and has the flexibility to penetrate several layers from a variety of angles (Kimberling, 1981).

Strictly speaking it is a theory of terminology that deals with human motives: What are people doing and why are they doing it? The method provides a structure to answer these questions that also reveals the perspective from which the judgment is made. This is accomplished through Burke's Pentad -- the five terms: act, scene, agent, agency, and purpose. "Act" names what took place in thought or deed; what was done. "Scene" provides the background of the act, the situation in which it occurred, when and where it was done. "Agent" refers to the person performing that act, who did it. "Agency" is the means or instruments used in the act, how it was done. And "Purpose" accounts for why it was done (Burke, 1945). These terms can roughly correlate to the following "art" terms: Act -- art object, Agent -- viewer, Agency -- artist(s), Scene -- culture, and Purpose -- intent. Ten permutations result from manipulating the terms: scene/act, scene/agency, scene/purpose, scene/agent, act/purpose, act/agent, act/agency, agent/purpose, agent/agency, and agency/purpose (or in art terms: object/culture, object/viewer, object/artist, object/purpose, culture/viewer, culture/artist, culture/purpose, viewer/artist,viewer/purpose, and artist/purpose). These ratios focus on specific relationships between terms in the Pentad, and are useful during analysis.

The terms are simplistic and easy to understand, yet their range is far. All terms are necessarily ambiguous, because they overlap into one another. Human motives can be shown to arise out of them and to terminate in them, because the Pentad is a generating principle.

We have likened the terms to the fingers, which in their extremities are distinct from one another, but merge in the paim of the hand. If you would go from one finger to another without a leap, you need but trace the tendon down into the palm of the hand then trace a new course along another tendon. (Burke, 1968, p. 19)

If you reduce the terms to any one of them, you will find all of them branching out again; one is not enough. It is by reason of the pliancy among the terms that philosophic systems can pull one way and another. The margins of overlap provide access (without a leap) to any other term. No great dialectical enterprise is necessary if the terms merge. If you reduce the pentad to one term and treat this as the essential terms -- the causal ancestor -- then you may proceed across the margins of overlap, deducing the other terms from it as the logical descendents.

The method has numerous applications. One could analyze a specific pentad, or compare one's pentad with anothers' viewing the same object, or examine one or more of the ratios in any one pentad, or alter one or 
more of the terms in the pentad to reveal other perspectives, or use the pentad to deconstruct criticism in periodicals, textbooks, etc. What one does depends upon the desires of the instructor and/or the student. The power of this method is its flexibility, scope, and complexity/simplicity.

When analyzing a pentad, numerous approaches can be taken, depending upon one's intent. Each term can be discussed separately. For instance, the Act (art form) might be formally analyzed; perhaps using Feldman's description, analysis, interpretation, evaluation steps. This could lead into a discussion of Agency (artists). Who are the artists? How does this relate to the art forms they create? This would lead into the expanding or narrowing the Scene (context): For whom is the work intended? When? What economic enterprises does it involve? How has the context changed? This leads into discussion of Agency (the viewer's role) and Purpose (why was this art form made? Why does it look, function as it does? etc.) One can see how involved this may get. It also illustrates how connected the terms are.

There are numerous other ways of dealing with a specific pentad. One might ask how the purpose influences opinion. One could examine how timing might influence evaluation. Each term could be stretched or hypothesized to illustrate the fact that it is but one of an endless number of viewpoints.

The procedure for the study entails a survey of present art criticism to see the evolution of, and alternatives to the prevailing classroom approach. The hypothesis is that Burke's Dramatism can be used as a superior alternative to what presently exists as classroom art criticism. Grounding Burke's Pentad in a philosophy of aesthetics, then explaining and adapting the method to visual forms rather than literary forms follows. This includes an examination of the issues of defining art, providing a cultural context, allowing a panoramic response, respecting the inherent qualities of the art form, and being democratic and dialectic in nature; showing that Burke's Dramatist Pentad can effectively deal with all of these factors. The method is applied to various art forms (fine arts, popular arts, folk arts, ethnic arts, children's art, nature, non art) under various circumstances, illustrating how it overcomes the limitations of the present traditional approach. The Pentad is also used to analyze other approaches to criticism. The study concludes with a discussion of the method and other applications as well as implications for further research.

Traditional classroom art criticism -- focusing on the fine arts, formalism, and the professional art critic -- does not directly or sufficiently deal with the art of the majority of students (Sutopo, 1987). This dissertation is an attempt to move art education in the direction of social relevance, individualism, and cultural pluralism, by seeking a method of classroom art criticism that does more than formal analysis of the fine arts, and hopefully moves toward a better, more just world. 


\section{References}

Apple. M. J. (1979). Ideology and curriculum. London: Routledge and Kegan Paul.

Apple. M. J. (1982). Cultural and economic reproduction in education. London, Boston, and Henley: Routledge \& Kegan Paul.

Arnheim, R. (1974). Visual thinking. Berkeley: University of California Press.

Atkins, S. S. (1989). The effectiveness of a studio-based art appreciation curriculum. (Doctoral dissertation, University of Georgia, 1986). Dissertation Abstracts International, 47/06A, p. 1989.

Barkan, M. (1966). Curriculum problems in art education. In E. L. Mattil (Ed.), A seminar in art education for research and curriculum development (pp. 240-255). University Park, PA: Pennsylvania State University.

Barkan, M., Chapman, L. H., and Kearn, E. J. (1970). Guidelines: Curriculum development for aesthetic education. CEMREL.

Beyer, L. E. (1981). Aesthetics and the curriculum: Ideological and cultural form in school practice. (Doctoral dissertation, University of Wisconsin, 1981).

Borgmann, C. B. (1981). A theoretical model for aesthetic education constructed from graph analysis and criticism of Broudy's and Feldman's theories. (Doctoral dissertation, Indiana University, 1981). Dissertation Abstracts International, 42/08A, p. 3393.

Brock, B. L. (1985). Epistemology and ontology in Kenneth Burke's dramatism. Communication Quarterly, 33 (2), pp. 94-104.

Burke, K. (1945). A grammar of motives. New York: Prentice Hall, Inc.

Burke, K. (1968). Language as symbolic action: Essays on life, literature and method. Berkeley: University of California Press.

Burke, K. (1968). Dramatism. International Encyclopedia of Social Sciences, 7, pp. 445-52.

Burgin, B. (1973) Work and commentary. London: Latimer New Dimensions, Limited.

Carpentier, R. (1987). Concepts of empathy and the nature of aesthetic response applied to visual art appreciation. (Doctoral dissertation, The 
Ohio State University, 1987). Dissertation Abstracts International, 48/09A, p. 2225.

Chapman, L. H. (1978). Approaches to art in education. New York: Harcourt Brace Jovanovich.

Chapman, L. H. (1982). Instant art, instant culture: The unspoken policy for American schools. New York: Teachers College, Columbia University.

Christian-Smith, L. K. (1987). Gender, popular culture, and curriculum: Adolescent romance novels as gender text. Curriculum Inquiry, 17 (4), pp. 1-30.

Clark, S. A. H. (1973) Modern theoretical foundations of appreciation and creation in art education textbooks 1960-1970. (Doctoral dissertation, University of Wisconsin, 1973).

Clark, G. A. (1977). The blind are leading the blind. OAEA Journal, 16 (3), pp. 9-12.

Clark, G. and Zimmerman, E. (1978). A walk in the right direction: A model for visual arts education. Studies in Art Education, 19, 34-39

Crawford, M. C. (1987). The educational philosophy of Maxine Greene: The role of the arts in teacher education. (Doctoral dissertation, Temple University, 1987). Dissertation Abstracts International, 48/04A, p. 865.

Dewey, J. (1934). Art as experience. New York: Minton, Balch, and Company.

Donahue, P. R. (1985). Visual hermeneutics: A bridge between the visual and the discursive (art criticism, interpretation, symbolization). (Doctoral dissertation, Graduate Theological Union, 1985).

Dissertation Abstracts International, 46/04A, p. 876.

Duncum, P. (1987). What, even Dallas: Popular culture within the art curriculum. Studies in Art Education, 29 (1), pp. 6-16.

Duvall, R. P. (1986). Educational criticism: Perceptions of values, criticism, and appreciation as aesthetic education across arts disciplines. (Doctoral dissertation, Saint Louis University, 1986). Dissertation Abstracts International, 48/04A, p. 892.

Early, P. (1985). The arts: A critical examination of their status in contemporary society. (Doctoral dissertation, Texas Woman's University, 1985). Dissertation Abstracts International, 46/06A, 
p. 1645.

Edelman, M. (1982). Art as liberating political communication. IHS - Journal, 6, pp. 1-5.

Eisner, El. W. (1972). Educating artistic vision. New York: Macmillan.

Feinstein, H. (1989). The art response guide: How to read art for meaning, a primer for art criticism, Art Education, May 1989.

Feldman, E. B. (1981). Varieties of visual experience: Art as image and idea. (2nd Ed.). Englewood Cliffs, NJ: Prentice-Hall, Inc.

Gaitskell, C., Hurwitz, A. \& Day, M. (1982). Children and their art: Methods for the elementary school (4th Ed.). Chicago: Harcourt Brace Jovanovich.

Gardner, H. \& Winner, E. H. (1974). How children learn: Three stages of understanding art. Psychology Today, 9 (10), pp. 42-45.

Geahigan, H. G. (1979). An analytic study of art criticism in curriculum contexts. (Doctoral dissertation, The Ohio State University, 1979).

Dissertation Abstracts International, 40/10A, p. 5289.

Geertz, C. (1976). Art as a cultural system. Modern Language Notes, 91, pp. 1473-1499.

The Getty Center of Education in the Arts. (1985). Beyond creating: The place for art in American schools. Los Angeles: Author.

Goranov, K. (1981). History and the sociology of art. International Social Science Journal, 33 (4), p. 24.

Hollingsworth, P. L. (1982). The combined effect of mere exposure, counterattitudinal advocacy, and art criticism methodology on affect toward artworks on upper elementary and junior high students. (Doctoral dissertation, The University of Tulsa, 1982). Dissertation Abstracts International, 43/01A, p. 53.

Hurwitz, A. and Madeja, S. (1977). The joyous vision: A sourcebook for elementary art appreciation. Englewood Cliffs, NJ: Prentice Hall.

Janov, D. R. (1966). The effects of structured criticism upon the perceptual differentiation and studio compositional skills displayed by college students in an elementary art education course. (Doctoral dissertation, Ball State University, 1986). Dissertation Abstracts International, 47/10A, p. 3641. 
Johansen, P. (1982). Teaching aesthetic discerning through dialog. Studies in Art Education, 23 (2), 6-13.

Kauffeld, F. (1989). The nature of criticism, The University of Wisconsin.

Kimberling, R. K. (Doctoral dissertation, University of Southern California, 1981). Dissertation Abstracts International, 42/03A, p. 1223.

Kliebard, H. M. (1986). The struggle for the American curriculum 18931958. Boston: Routledge and Kegan Paul.

Kordich, D. D. (1982). An instructional strategy in art criticism for the middle school: A game approach focusing on the stage of analysis. (Doctoral dissertation, Indiana University, 1982). Dissertation Abstracts International, 43/04A, p. 1016.

Kostelanetz, R. (Ed.). (1976). Younger critics of North America; Essays on literature and the arts. Fairwater, Wisconsin: Tom Montog/Margin Books.

Landis, C. M. (1987). Classroom talk about artwork: Content of fifth and sixth grade art discussion activities. (Doctoral dissertation, University of Wisconsin, 1987). Dissertation Abstracts International, 49/01A, p. 396.

Langer, S. K. (1942). Philosophy in a new key: A study in the symbolism of reason, rite, and art (3rd Ed.). Cambridge, Massachusetts: Harvard University Press, 1980 (originally published in 1942).

Lanier, V. (1963). Schismogenesis in contemporary art education. Studies in Art Education, 5 (10), pp. 10-19.

Lanier, V. (1983). Beyond aesthetic education. Art Education, 36 (6), 31-37.

Lanier, V. (1987). ART, a friendly alternative to DBAE. Art Education, --- (-- ), pp. $46-50$.

Lankford, E. L. (1980). Merleau-Ponty's concepts of perception, behavior, and aesthetics applied to critical dialogue in the visual arts. (Doctoral dissertation, The Florida State University, 1980). Dissertation Abstracts International, 41/07A, p. 2890.

Mittler, G. (1973). Experiences in critical inquiry. Approaches for use in the art methods class. Art Education, 26 (2), p. 16-21.

The National Endowment for the Arts. (1988). Toward civilization in National art education association, NAEA News, 30, (4), pp. 3-9.

Working Papers in Art Education 1989 - 1990 
Pepper, S. C. (1949). Principles of art appreciation. New York: Harcourt, Brace \& Co.

Petkus, E. (1985). A critical analysis of aesthetics and its implications for the role of public philosophy and educational practice (social, experience). (Doctoral dissertation, Rutgers, The State University of New Jersey, 1985). Dissertation Abstracts International, 46/09A, p. 2612.

Rees, A. L. \& Borzello, F. (Eds.). (1988). The new art history. Atlantic Highlands, NJ.

Rosenberg, H. (1973). The De-definition of art. New York: Collier Books.

Smith, N. H. (1983). Art criticism and reading: Theoretical and psychological foundations. (Doctoral dissertation, University of Georgia, 1983).

Dissertation Abstracts International, 44/05A, p. 1303.

Sutopo, H. (1987). A model of art criticism for teaching appreciation of Japanese traditional art in Indonesia. (Doctoral dissertation, The Florida State University, 1987). Dissertation Abstracts International, 48/02A, p. 288.

Titchener, C. B. (1987). Reviewing the arts. Hillsdale, NJ: Lawrence Erlbraum Assoc., Inc.

Trachtenberg, M. (1989). Archaeology, merriment, and murder: The first cortile of the Palazzo Vecchio and its transformations in the late Florentine republic. The Art Bulletin, LXXI/4, p. 606.

Tyler, R. (1949). Basic principles of curriculum and instruction. Chicago: University of Chicago Press.

Wilson, B. D. (1987). Teaching drawing from art. Worcester, Mass.: Davis Publications.

Wolff, J. (1975). Aesthetics and the Sociology of Art. London: George Allen and Unwin. 